\title{
Growth and bioactive secondary metabolites of arctic Protoceratium reticulatum (Dinophyceae)
}

\author{
Manuel Sala-Pérez ${ }^{\mathrm{a}, 1}$, Tilman J. Alpermann ${ }^{\mathrm{b}}$, Bernd Krock ${ }^{\mathrm{a}}$, Urban Tillmann ${ }^{\mathrm{a}, *}$ \\ a Alfred Wegener Institute, Am Handelshafen 12, D-27570 Bremerhaven, Germany \\ ${ }^{\mathrm{b}}$ Senckenberg Research Institute and Natural History Museum, Senckenberganlage 25, D-60325 Frankfurt a.M., Germany
}

\section{A R T I C L E I N F O}

\section{Article history:}

Received 16 October 2015

Received in revised form 9 February 2016

Accepted 9 February 2016

\section{Keywords:}

Protoceratium reticulatum

Arctic

Temperature

Yessotoxin

Lytic activity

\begin{abstract}
A B S T R A C T
Harmful algal blooms are mainly caused by marine dinoflagellates and are known to produce potent toxins that may affect the ecosystem, human activities and health. Such events have increased in frequency and intensity worldwide in the past decades. Numerous processes involved in Global Change are amplified in the Arctic, but little is known about species specific responses of arctic dinoflagellates. The aim of this work was to perform an exhaustive morphological, phylogenetical and toxinological characterization of Greenland Protoceratium reticulatum and, in addition, to test the effect of temperature on growth and production of bioactive secondary metabolites. Seven clonal isolates, the first isolates of $P$. reticulatum available from arctic waters, were phylogenetically characterized by analysis of the LSU rDNA. Six isolates were further characterized morphologically and were shown to produce both yessotoxins (YTX) and lytic compounds, representing the first report of allelochemical activity in $P$. reticulatum. As shown for one of the isolates, growth was strongly affected by temperature with a maximum growth rate at $15{ }^{\circ} \mathrm{C}$, a significant but slow growth at $1{ }^{\circ} \mathrm{C}$, and cell death at $25^{\circ} \mathrm{C}$, suggesting an adaptation of $P$. reticulatum to temperate waters. Temperature had no major effect on total YTX cell quota or lytic activity but both were affected by the growth phase with a significant increase at stationary phase. A comparison of six isolates at a fixed temperature of $10{ }^{\circ} \mathrm{C}$ showed high intraspecific variability for all three physiological parameters tested. Growth rate varied from 0.06 to $0.19 \mathrm{~d}^{-1}$, and total YTX concentration ranged from 0.3 to $15.0 \mathrm{pg}^{\text {YTX cell }}{ }^{-1}$ and from 0.5 to $31.0 \mathrm{pg} \mathrm{YTX} \mathrm{cell}^{-1}$ at exponential and stationary phase, respectively. All six isolates performed lytic activity; however, for two isolates lytic activity was only detectable at higher cell densities in stationary phase.
\end{abstract}

(c) 2016 Elsevier B.V. All rights reserved.

\section{Introduction}

A number of marine plankton algae are known for the production of potent toxins and other bioactive compounds, they may also form Harmful Algal Blooms (HABs) causing human health problems, fish kills, and/or other ecosystem disruptions (Hallegraeff, 1993; Anderson et al., 2012). The frequency, intensity and geographic distribution of such blooms, and indications on a general phytoplankton community shift towards harmful species, have increased worldwide (Hallegraeff, 2010; Fu et al., 2012). Several forces might drive these changes such as ocean acidification, global warming, shifts in availability, ratios, and speciation of nutrients, changing exposure to solar irradiance, and altered

\footnotetext{
* Corresponding author. Tel.: +49 47148311470.

E-mail address: urban.tillmann@awi.de (U. Tillmann).

1 Present address: Institute of Environment, Health and Societies, Brunel University London, UB8 3PH Uxbridge, UK.
}

salinity; all these parameters have the potential to profoundly affect the growth and toxicity of these phytoplankton species (Fu et al., 2012). In addition, these factors and processes, as many others, are likely amplified in the Arctic by various feedbacks, including ice and snow melting that decreases surface albedo, and atmospheric stability that traps temperature anomalies near the surface. Consequently, the temperature in the Arctic is increasing at a rate of two to three times that of the global average temperature in the past 150 years (Wassmann et al., 2011). Without doubt temperature increase will affect growth of a variety of marine organisms altering their biogeographic distribution and boundaries. Thus, range extension of phytoplankton taxa responsible for HABs and toxin production into and within the Arctic are to be expected. In the past, a number of harmful eukaryotes have been recorded in marine plankton and sympagic communities across the entire Arctic region, with the domoic acid producing planktonic diatoms Pseudo-nitzschia delicatissima, Pseudo-nitzschia pungens and Pseudo-nitzschia seriata, the prymnesiophyte Phaeocystis pouchetii, and the dinoflagellates Azadinium sp., 
Amphidoma languida, Alexandrium tamarense, Alexandrium ostenfeldii, Dinophysis acuminata, Dinophysis acuta, Dinophysis norvegica, Gonyaulax spinifera, and Protoceratium reticulatum as the most abundant species (Okolodkov, 2005; Poulin et al., 2011; Tillmann et al., 2014).

Protoceratium reticulatum (Syn. P. aceros, Gonyaulax grindleyi) is a gonyaulacoid dinoflagellate with a taxonomic and nomenclatural history dating back to 1858 when Claparade \& Lachman first described the species as Peridinium reticulatum (Hansen et al., 1996/97). The species is fairly common and widely distributed in coastal waters around the world-although it is genetically subdivided into two evolutionary clades, for which distinct distribution ranges are currently known (see Akselman et al., 2015, and references therein). A main event gaining attention was when Protoceratium recticulatum was identified as a producer of yessotoxins (YTX), first confirmed in cultures of $P$. reticulatum from New Zealand (Satake et al., 1997). Yessotoxins, a group of disulfated polyether toxins, were first isolated from Japanese scallops by Murata et al. (1987). Effects of YTX tested in mice seem to be more serious when YTX are supplied by intraperitoneal injection than oral administration. There are reports on damages in cardiac muscle (Aune et al., 2002), liver and pancreas (Terao et al., 1990), and neuronal tissue (Franchini et al., 2004) by intraperitoneal YTX supply in mice. Consequently, YTX should be considered a potential risk for human health with a lethal dose (LD50) between 80 and $750 \mu \mathrm{g} / \mathrm{kg}$ (Paz et al., 2008). Besides the possible toxic effects of YTX, it has been suggested that YTX may act as a defense against grazers as feeding rates by copepods were significantly reduced in the presence of YTX (Makino et al., 2008). Yessotoxin has been found in bivalves and phytoplankton samples in many places around the world (Paz et al., 2008), with records from Norway (Ramstad et al., 2001; Miles et al., 2004) and the Russian White Sea (Vershinin et al., 2006), indicating a subarctic and arctic occurrence. A future expansion in distribution and an increase in bloom formation potential of toxin producing species such as $P$. reticulatum will have a significant impact, as marine products are assumed to be of increasing economic importance for Greenland and other arctic and subarctic regions. It is therefore of priority to gain some baseline information on harmful algae bloom forming species actually present in the Arctic and to generate specific knowledge on how a changing environment may affect physiological aspects like growth and toxin production.

In summer 2012, a research cruise was performed on board the research vessel Maria S. Merian to the West coast of Greenland with a focus on Arctic phytoplankton species diversity and an emphasis on HAB species. During that cruise the presence of Protoceratium reticulatum in Greenland coastal waters was recorded and a number of clonal cultures were successfully established. This allowed for the first time a morphological, phylogenetical and toxinological characterization of Greenland P. reticulatum populations. Moreover, this facilitated a detailed experimental study on effects of temperature on growth and production of bioactive secondary metabolites thereby providing baseline data on the physiological adaption and acclimatization potential of the species under future climate change in the Arctic.

\section{Materials and methods}

\subsection{Isolation and identification of Protoceratium reticulation}

A total of seven clonal isolates of Protoceratium reticulatum (PR1 to PR7) were collected from plankton samples in Greenland's western coastal waters (Fig. 1, PR2 isolated from Stat. 524, all others isolated from Stat. 516) during the ARCHEMHAB cruise aboard the research vessel Maria S. Merian in August 2012 (MSM21/3). Vertical net tows were performed at each station

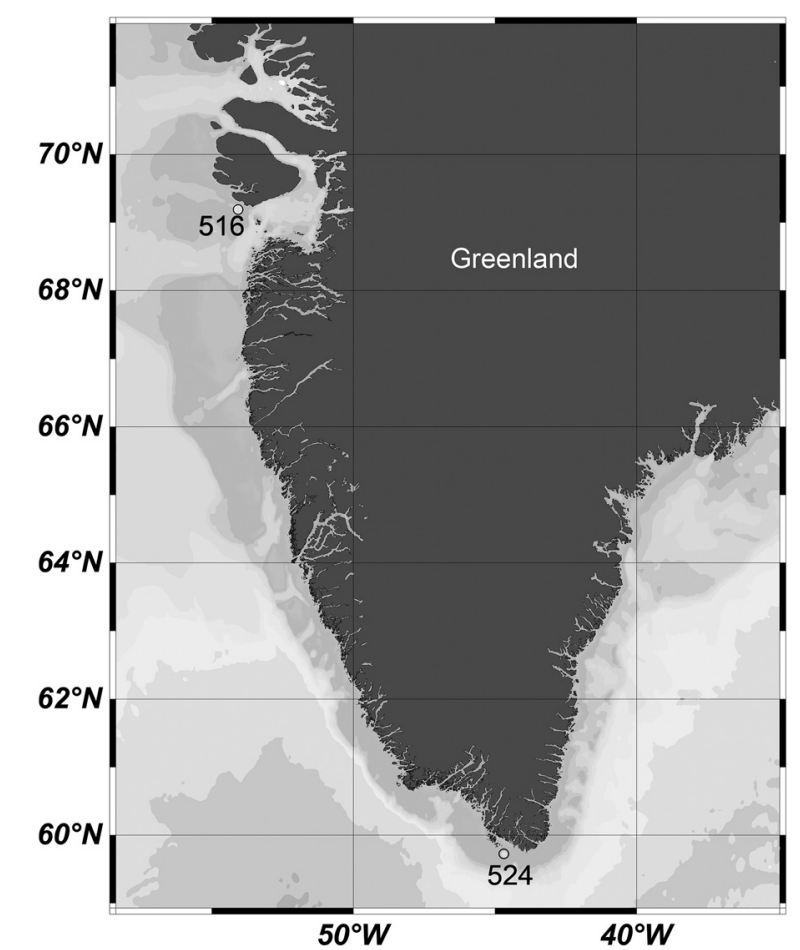

Fig. 1. Map of southern Greenland indicating two of the stations performed during the cruise on the research vessel Maria S. Merian in August of 2012, where the clonal isolates of $P$. reticulatum were isolated (stations 516 and 524).

through the upper $30 \mathrm{~m}$ of the water column with a $20-\mu \mathrm{m}$-mesh Nitex plankton net. Single cells of $P$. reticulatum were isolated on board from live net tow concentrates under a stereomicroscope (M5A, Wild, Heerbrugg, Switzerland) by micropipette. Single cells were transferred into individual wells of 96-well tissue culture plates (TPP, Trasadingen, Switzerland) containing $250 \mu \mathrm{L}$ of medium prepared from $0.2 \mu \mathrm{m}$ sterile-filtered natural Antarctic seawater K-medium (Keller et al., 1987) diluted with seawater from the sampling location at a ratio of $1: 10$. Plates were incubated at $10{ }^{\circ} \mathrm{C}$ in a controlled environment growth chamber (Model MIR 252, Sanyo Biomedical, Wood Dale, USA). After 3 to 4 weeks, unialgal isolates were transferred to 24 -well tissue culture plates, each well containing $2 \mathrm{~mL}$ medium. Exponentially growing isolates were finally used as inoculum for batch cultures in $65 \mathrm{~mL}$ polystyrene cell culture flasks and were maintained thereafter at $10{ }^{\circ} \mathrm{C}$ under a photon flux density of $30-50 \mu \mathrm{mol} \mathrm{s}{ }^{-1} \mathrm{~m}^{-2} 16: 8 \mathrm{~h}$ light:dark photocycle in a temperature-controlled walk-in growth chamber. One of the isolates was lost after a first sampling for DNA (see below). The remaining six isolates were morphologically identified by light and fluorescence microscopy of calcofluorstained samples. Characterization of thecal ornamentation, and number and arrangement of thecal plates, was carried out with epifluorescence after applying a few drops of $1 \mathrm{mg} \mathrm{L}^{-1}$ solution of Fluorescent Brightener 28 (Sigma-Aldrich). Additionally, the plate pattern was analyzed using an electron microscope (FEI Quanta FEG 200, Eindhoven, The Netherlands). Therefore, a sample of isolate PR3 from an exponentially growing culture was fixed with Lugol (1\% final concentration), collected on a polycarbonate filter ( $5 \mu \mathrm{m}$ pore size, Millipore), dehydrated, mounted on stubs, and sputter-coated as described in Tillmann et al. (2010, 2011).

All seven clonal isolates of Protoceratium reticulatum were grown and harvested during exponential phase by centrifugation in $50 \mathrm{~mL}$ conical tubes. Genomic DNA was extracted from cell pellets using a DNeasy Plant Mini Kit (Qiagen, Hilden, Germany) according to the manufacturer's instructions as described in detail by Toebe et al. (2013). From the resultant DNA the D1/D2 hypervariable region of 
the large sub-unit (LSU) of the ribosomal operon was PCR amplified and Sanger sequenced with the primers D1R (forward) and D2C (reverse) (Scholin et al., 1994) and PCR chemistry, cycling and sequencing conditions as in Akselman et al. (2015). Forward and reverse sequences were assembled in Geneious Pro 5.4.4 (Biomatters Ltd., Auckland, New Zealand) and a BLAST search was conducted with the resultant sequences in order to identify other $P$. reticulatum from GenBank. Sequences of $P$. reticulatum and the resultant set of other $P$. reticulatum sequences were aligned in MAFFT v7.017 (Katoh and Kuma, 2002; Katoh and Standley, 2013) using a plugin for Geneious Pro. Additional sequences in the alignment corresponded to those gonyaulacoid dinoflagellates used in the phylogenetic analysis by Akselman et al. (2015) that built up on a previous analysis in Howard et al. (2009), but additionally included a set of sequences representing the five ribotypes of the Alexandrium tamarense/A. fundyense/A. catenella species complex and a sequence of Prorocentrum minimum as the out-group (see Supplementary material, Table S01). The resultant alignment was restricted to the length of the sequences of the clonal isolates of $P$. reticulatum from Greenland and sequences of $P$. reticulatum "Clade A" (sensu Akselman et al., 2015) that were identical were removed from the alignment. The best fitting model of nucleotide substitution was determined according to scores of the Akaike Information Criterion in jModeltest 0.1.1 (Posada, 2008) and a Maximum Likelihood (ML) tree was constructed using the TIM1+G model of nucleotide substitution in PhyML (Guindon and Gascuel, 2003) via a plugin in Geneious Pro. Reliability of tree topology was estimated by 200 bootstrap replicates.

\subsection{Temperature experiments}

In order to estimate the growth response of arctic Protoceratium reticulatum to varying temperature, one of the isolates (PR3) was chosen for detailed growth experiments at six temperatures $(1,5,10$, 15,20 and $25^{\circ} \mathrm{C} \pm 1{ }^{\circ} \mathrm{C}$ ). Cultures were pre-adapted gradually by steps of five degrees to the respective experimental temperature before starting the experiment. Therefore, the culture of PR3, which was routinely kept at $10^{\circ} \mathrm{C}$, was first split and moved also to $5{ }^{\circ} \mathrm{C}$ and $15^{\circ} \mathrm{C}$. After a couple of cell divisions, these cultures again were split and moved to $1{ }^{\circ} \mathrm{C}$ and $20^{\circ} \mathrm{C}$ respectively, and finally to $25^{\circ} \mathrm{C}$. Cultures used to inoculate the experiment were thus kept at the experimental temperature for at least five generations (at $1{ }^{\circ} \mathrm{C}$ due to the slow growth) to at least ten generations at the higher temperatures.

At each temperature, triplicate cultures were set up in $250 \mathrm{~mL}$ tissue flasks in $1 / 10 \mathrm{~K}$-medium at an initial concentration of 300500 cells $\mathrm{mL}^{-1}$ at photon flux density of 80-90 $\mu \mathrm{mol} \mathrm{s}^{-1} \mathrm{~m}^{-2} 16: 8 \mathrm{~h}$ light:dark photocycle. Cultures were sampled for cell counts in intervals of two to five days, depending on the growth rate. Previous to each sub-sampling, culture flasks were gently shaken by hand for a homogenous cell distribution. For yessotoxin quantification, lysisbioassay experiments, and cell size estimates, samples were taken in the exponential phase at a cell density of about 2000 cells $\mathrm{mL}^{-1}$ and in stationary phase, when at least three consecutive cell counts indicated no further increase in cell density.

\subsection{Experiments on isolate variability}

All six available isolates were grown at $10{ }^{\circ} \mathrm{C}$ to test for clonal variability of growth, lytic activity, and YTX content. The cultures were grown and sampled exactly as described above.

\subsection{Analyses}

\subsubsection{Cell counts and growth rate estimates}

Cell density was measured by cell counting in sedimentation chambers with an inverted microscope (Zeiss Axiovert 40C,
Göttingen, Germany) of samples fixed with Lugol's solution (1\% final concentration). Depending on the cell concentration the volume fixed for cell counting varied from 0.1 to $1 \mathrm{~mL}$, so that the total number of cells counted was always $>300$. Specific growth rate $\left(\mu\right.$, day $\left.^{-1}\right)$ was calculated separately for each replicate by exponential regression of cell density over time for a defined period of exponential growth. Growth curves for each isolate were plotted from mean cell density of the three replicates.

\subsubsection{Cell size}

To determine cell size, Lugol fixed (1\% final concentration) cells were viewed under an inverted microscope (Zeiss Axiovert $200 \mathrm{M}$, Zeiss, Göttingen, Germany) and photographed at $640 \times$ magnification with a digital camera (Axiovert, Zeiss, Germany). Measurements were taken using the analysis tool of the Axiovision software (Zeiss, Germany). A total of 30 cells were measured in length and width of each of the three replicate cultures. For statistical analysis cell size data of the replicate cultures were combined yielding 90 size data for each treatment.

\subsubsection{Quantification of yessotoxins}

For quantification of YTX, $2 \times 50 \mathrm{~mL}$ (technical duplicates) of each culture replicate in exponential phase, and $2 \times 15 \mathrm{~mL}$ in stationary phase, were centrifuged at $3220 \times \mathrm{g}$ for $15 \mathrm{~min}$ at $4{ }^{\circ} \mathrm{C}$ using 50 and $15 \mathrm{~mL}$ centrifuge tubes, respectively. Algal pellets for quantification of intracellular YTX were transferred to $2 \mathrm{~mL}$ microcentrifuge tubes and stored at $-20{ }^{\circ} \mathrm{C}$ until analysis. The supernatant was stored at $-20^{\circ} \mathrm{C}$ in glass bottles for quantification of extracelluar YTX.

2.4.3.1. Intracellular YTX. Pellets (technical duplicates for each replicate culture and sampling) were extracted with $0.5 \mathrm{~mL}$ of methanol (MeOH) using a FastPrep ${ }^{\circledR}$ FP120 Cell Disrupter for $45 \mathrm{~s}$ at $6.5 \mathrm{~m} \mathrm{~s}^{-1}$ by reciprocal shaking, then the samples were centrifuged at $13,200 \times g$ for $15 \mathrm{~min}$. The supernatant was transferred to a $1 \mathrm{~mL}$ tube with a spin filter with a pore diameter of $0.45 \mu \mathrm{m}$ and was centrifuged at $9300 \times g$ for $30 \mathrm{~s}$. Samples were stored at $-20^{\circ} \mathrm{C}$ in autosampler vials until measurement by LC-MS/MS.

2.4.3.2. Extracellular YTX. Extracellular YTX was extracted from the cell free supernatant by solid phase extraction (SPE). First, C18 SPE cartridges ( $6 \mathrm{~mL}$, Supelclean, Supelco, Deisenhofen, Germany) were conditioned with $2 \mathrm{~mL}$ methanol, then $2 \mathrm{~mL} \mathrm{50 \%} \mathrm{aqueous}$ methanol and equilibrated with $2 \mathrm{~mL}$ water. Then samples were loaded on the cartridges and salts were removed with $3 \mathrm{~mL}$ water. Yessotoxins were eluted with $9 \mathrm{~mL}$ methanol. As quality control, eluted cartridges were additionally eluted with $1 \mathrm{~mL}$ methanol. The main eluates were reduced to volumes $<0.5 \mathrm{~mL}$ in a rotary evaporator $\left(50{ }^{\circ} \mathrm{C}\right.$ water bath, 125 mbar, Büchi, Konstanz, Germany), transferred to HPLC vials and adjusted to $1 \mathrm{~mL}$ with methanol and kept at $-20{ }^{\circ} \mathrm{C}$ until analysis. Yessotoxin recovery of this procedure was assessed by application of spiked culture medium. Cell extracts (isolate PR3) containing $500 \mathrm{ng}$ YTX were spiked to $50 \mathrm{~mL}$ culture medium and processed as described above.

Yessotoxin recovery of solid phase extraction (SPE) on C18 cartridges was determined as $52 \pm 7 \%$ in three replicates. The measured extracellular YTX values were back calculated accordingly to $100 \%$ in all experiments.

2.4.3.3. LC-MS/MS analyis. Measurements were carried out on a triple quadruple mass spectrometer (API 4000 QTrap, AB-Sciex) with turbo spray ionization in the negative mode. Separation was performed on a reversed phase BDS C8 column $(50 \times 2 \mathrm{~mm}, 3 \mu \mathrm{m}$, 
Table 1

Mass transitions of the SRM experiments and their respective YTX. All compounds and entries refer to numbering in Miles et al. (2005a,b).

\begin{tabular}{|c|c|c|}
\hline Q1 mass $(m / z)$ & Q1 mass $(m / z)$ & YTX \\
\hline 991 & 911 & Compounds 17-19 \\
\hline 1047 & 967 & $\begin{array}{l}\text { 41-keto-YTX, 40-epi-41-keto-YTX, } \\
\text { 41-keto-YTX-enone (compounds 6,7,8) }\end{array}$ \\
\hline 1049 & 969 & Undescribed \\
\hline 1061 & 981 & Entries 21, 22 \\
\hline 1085 & 1005 & Compound 16 \\
\hline 1101 & 1021 & Nor-YTX (compound 5) \\
\hline 1117 & 1037 & Entry 17 \\
\hline 1131 & 1051 & Undescribed \\
\hline 1141 & 1061 & YTX, entries (32-35) \\
\hline 1143 & 1063 & Entry 37 \\
\hline 1155 & 1075 & 41a-homo-YTX (compound 5) \\
\hline 1157 & 1077 & 45-OH-YTX (compound 2) \\
\hline 1159 & 1079 & Entry 45 \\
\hline 1169 & 1089 & 9-Me-41a-homo-YTX (compound 10) \\
\hline 1171 & 1091 & Undescribed \\
\hline 1173 & 1093 & Carboxy-YTX (compound 3) \\
\hline 1175 & 1095 & 44,55-dihydroxy-YTX (compound 13) \\
\hline 1187 & 1107 & Entries $57-60$ \\
\hline 1189 & 1109 & Compound 14 \\
\hline 1195 & 1115 & Undescribed \\
\hline 1203 & 1123 & Compound 15 \\
\hline 1273 & 1193 & Compound 20 \\
\hline 1290 & 1210 & Compound 11 \\
\hline 1304 & 1224 & Compound 12 \\
\hline 1405 & 1325 & Compound 21 \\
\hline
\end{tabular}

$120 \mathrm{~A})$ at a flow rate of $0.3 \mathrm{~mL} \mathrm{~min}^{-1}$ using an elution gradient with two eluents (A: water and B: 95\% acetonitrile/methanol $(1: 2 \mathrm{v} / \mathrm{v})$ and $5 \%$ water, both eluents containing $2.0 \mathrm{mM}$ ammonium formate and $50 \mathrm{mM}$ formic acid). Initial composition was $40 \% \mathrm{~B}$. A linear gradient to $100 \% \mathrm{~B}$ was performed from 0 to $6 \mathrm{~min}$ followed by isocratic elution with $100 \% \mathrm{~B}$ until $15 \mathrm{~min}$, then returning to initial conditions until $16 \mathrm{~min}$ and $12 \mathrm{~min}$ column equilibration (total run time $28 \mathrm{~min}$ ). Yessotoxins were detected in the selected reaction monitoring (SRM) mode and the transitions shown in Table 1 were used. Yessotoxin was identified by comparing retention times and mass transitions of samples and a reference standard (IMB-NRC, Halifax, Canada). All other yessotoxins were calibrated against the YTX standard and expressed as YTX equivalents. Results are expressed as YTX cell quota (pg YTX cell ${ }^{-1}$ ).

\subsubsection{Quantification of lytic effects}

A routine screening of Greenland isolates for lytic activity indicated that all Protoceratium reticulatum cultures were positive. Consequently, the allelochemical effect of $P$. reticulatum was quantified with a short-term $(24 \mathrm{~h})$ lysis bioassay with the cryptophyte Rhodomonas salina as target organism. A culture of $R$. salina (strain KAC 30 from the Kalmar culture collection) was maintained in $100 \mathrm{~mL}$ Erlenmeyer flask at $15{ }^{\circ} \mathrm{C}$ in $\mathrm{K}$-medium as described before, at a photon flux density of $30 \mu \mathrm{mol} \mathrm{s}{ }^{-1} \mathrm{~m}^{-2}$ 16:8 h light:dark photocycle. Counting the number of intact $R$. salina cells (normal cell shape still visible) after $24 \mathrm{~h}$ incubation with $P$. reticulatum samples enabled quantification of lytic effect. In order to quantitatively compare the lytic potency, dose-response curves covering a varying number of different $P$. reticulatum cell concentrations were performed.

Bioassays were performed as follows: cell concentration of a stock culture of Rhodomonas salina was determined by microscope cell count and an aliquot was subsequently diluted to a concentration of $4.0 \times 10^{5} \mathrm{~mL}^{-1}$. Each set of experimental vials containing $3.9 \mathrm{ml}$ of different dilutions of Protoceratium reticulatum (each dilution performed in duplicates) was inoculated with $0.1 \mathrm{~mL}$ of $R$. salina (final cell concentration $1.0 \times 10^{3} \mathrm{~mL}^{-1}$ ) to start the experiment. Three replicates of $3.9 \mathrm{~mL}$ filtered seawater were taken as control. Vials were incubated at the respective experimental temperature in absence of light to prevent growth. After $24 \mathrm{~h}$, samples were gently shaken and a subsample of $0.5 \mathrm{~mL}$ was fixed with $1 \%$ Lugol's solution in a sedimentation chamber and cell density of both $R$. salina intact cells and $P$. reticulatum were determined by invert microscope counts. For $P$. reticulatum whole chambers were counted, while for $R$. salina three sub-areas corresponding to approximately 600 cells in the controls were counted.

Bioassays for PR3 grown at different temperatures were performed using a series of 10 dilutions (from undiluted culture to about 20 cells $\mathrm{mL}^{-1}$ ). In these experiments, final concentrations of intact Rhodomonas salina cells followed a sigmoidal declining pattern when plotted against log-transformed Protoceratium reticulatum cell concentrations. In order to estimate the $\mathrm{EC}_{50}$ concentrations (i.e. P. reticulatum cell concentration yielding a $50 \%$ decline in $R$. salina cell concentration), data points were fit to the following non-linear model procedure in Statistica ${ }^{\circledR}$ :

$N_{\text {final }}=\frac{N_{\text {control }}}{\left(1+\left(\left(x / E C_{50}\right)^{h}\right)\right)}$

where $N_{\text {final }}$ is the final Rhodomonas salina cell concentration, $N_{\text {control }}$ is the final $R$. salina cell concentration in control samples (1/10 K-medium inoculated with $1.0 \times 10^{3}$ cells of $R$. salina), $\mathrm{x}$ is the log-transformed Protoceratium reticulatum concentration and $\mathrm{EC}_{50}$ and $h$ are fit parameters. In order to visually compare all curves, (which are slightly different in $R$. salina control concentration), plots were normalized by setting the control as $100 \%$.

For the comparison of the six clonal isolates a full set of dilutions could not be performed. Here three (exponential phase) or four (stationary phase) different dilutions were tested, which at least allowed a rough comparison against the isolate PR3. Therefore the curve fitted for the full dose response curve of PR3 was shifted by eye to match the data points of the respective isolate and to roughly evaluate the $\mathrm{EC}_{50}$ concentration.

An initial bioassay experiment was performed to quantify and compare lytic activity of whole culture, of cell free supernatant, and of cell extract. Therefore, a culture of isolate PR3 was grown at $15{ }^{\circ} \mathrm{C}$ at the standard culture conditions described above and sampled at a cell density of 4205 cells $\mathrm{mL}^{-1}$. To differentiate between intra- and extracellular lytic activity cells and medium were separated by centrifugation of $100 \mathrm{~mL}$ of the culture at $3220 \times \mathrm{g}$ for 15 minutes at $4{ }^{\circ} \mathrm{C}$ using $50 \mathrm{~mL}$ centrifuge tubes. Subsequently a whole set of 10 different dilutions ranging from 4100 cells $\mathrm{mL}^{-1}$ to 130 cells $\mathrm{mL}^{-1}$ (each as duplicates) was prepared for both the whole cell culture and the cell-free supernatant. The cell pellets were combined and re-suspended in $1 \mathrm{~mL}$ of $1 / 10 \mathrm{~K}$-medium. Algal extract was prepared as described by Eschbach et al. (2001): the cell suspension was sonicated with a Sonoplus HD70 disintegrator equipped with a MS73 sonotrode (Bandelin Electronics, Berlin, Germany) using the following settings: $50 \%$ pulse cycle, $70 \%$ amplitude for $1 \mathrm{~min}$ on ice. During the whole preparation procedure, algal extract was kept on ice. The lytic activity of the algal extract was tested simultaneous with the whole cell and supernatant with a set of dilutions.

\subsection{Statistics}

Statistical comparisons of the growth rate, YTX concentration, and lytic activity of Protoceratium reticulatum at different temperatures were compared by analysis of the variance (ANOVA) and Tukey's HSD post-hoc tests. Likewise, significant differences between the six clonal isolates from the Arctic were tested by ANOVA and Tukey's HSD post-hoc. 


\section{Results}

\subsection{Morphologic and molecular characterization of Protoceratium reticulation}

Cells of Protoceratium reticulatum from Greenland were generally subsphaeroideal and slightly longer than wide, but variable in cell shape and size. The mean of all measurements (all isolates, all temperatures, all growth phases) was $31.1 \pm 3.4 \mu \mathrm{m}$ for cell length and $1.09 \pm 0.08$ for the length/width ratio, respectively $(n=1800)$. Cell size was slightly but significantly different among different isolates (e.g., for cell length in exponential phase: $F=40.1 ; P<0.0001)$. In addition, temperature slightly but significantly affected cell size as well $(F=12.7, P<0.0001)$ with slightly smaller cells at higher temperatures (Table 2 ).

The cingulum was located above the median line and was deeply incised and displaced about one cingulum width (Fig. 2A-C, $\mathrm{H}$ and $\mathrm{I})$. The cells had a very ornamented theca with raised ridges and numerous pores in the cellulosic plates, with a single pore in each of the polygonal ornamentation (Fig. 2D and E). On the first apical plate a large ventral pore was visible (arrow in Fig. 2G). The plate pattern was identified by electron microscopy. On the hypotheca, the large posterior sulcal plate (S.p.), five postcingular plates ( $\left.5^{\prime \prime \prime}\right)$, and two antapical plates ( $\left.2^{\prime \prime \prime \prime}\right)$ were identified (Fig. $\left.2 \mathrm{~J}\right)$. The epithecal plates consisted of a drop-shaped pore plate (po), three apical plates $\left(3^{\prime}\right)$, one intercalary plate (1a), and six precingular plates $\left(6^{\prime \prime}\right)$ (Fig. $2 \mathrm{~F}, \mathrm{~K}$ and $\mathrm{L}$ ). As exemplarily documented for the isolate PR3 there was some variability in the location of the intercalary plate (Fig. 2M-O). The suture length between the apical Plates $2^{\prime}$ and $3^{\prime}$ was quite variable and in many cases so small that it was difficult to decide if in fact Plate 1a touched the pore plate. In a few cases, Plate 1a without doubt was in contact to the pore plate and clearly separated Plates $2^{\prime}$ and $3^{\prime}$ (Fig. 20).

The maximum likelihood (ML) analysis showed that all seven clonal isolates of Protoceratium reticulatum from Greenland were identical to most other sequences of $P$. reticulatum that were included in the multiple sequence alignment. In the present ML tree, all $P$. reticulatum were part of a monophyletic clade that subdivided into two well supported, divergent sub-clades. The sequences of the isolates fell in the same clade as the majority of sequences of $P$. reticulatum ("Clade A" according to Akselman et al., 2015), and only three isolates of $P$. reticulatum comprised the

\section{Table 2}

Protoceratium reticulatum, cell size of isolate PR3 at different temperatures (upper half) and of all isolates grown at $10^{\circ} \mathrm{C}$ (lower half) in exponential and stationary growth phase. Cell length $(\mu \mathrm{m})$ and the ratio of cell length and width (ratio $\mathrm{L} / \mathrm{W}$ ) are given. Each value is the mean of the 30 cell measurements $\times 3$ replicates for each treatment $(n=90) \pm 1$ SD. Capital letters indicate classification of samples forming homogenous groups (ANOVA, Tukey's HSD test, $P<0.05$ ).

\begin{tabular}{clllll}
\hline & \multicolumn{2}{l}{ Exponential } & & \multicolumn{2}{l}{ Stationary } \\
\cline { 2 - 3 } \cline { 5 - 6 } \cline { 5 - 6 } & Length & Ratio L/W & & Length & Ratio L/W \\
\hline Temperature $\left({ }^{\circ} \mathrm{C}\right)$ & & & & \\
1 & $32.1 \pm 3.1^{\mathrm{C}}$ & $1.07 \pm 0.04^{\mathrm{A}}$ & & $34.3 \pm 3.3^{\mathrm{B}}$ & $1.05 \pm 0.06^{\mathrm{A}}$ \\
5 & $32.2 \pm 3.5^{\mathrm{C}}$ & $1.09 \pm 0.06^{\mathrm{A}}$ & & $35.0 \pm 3.2^{\mathrm{B}}$ & $1.06 \pm 0.05^{\mathrm{AB}}$ \\
10 & $29.6 \pm 3.0^{\mathrm{AB}}$ & $1.13 \pm 0.09^{\mathrm{B}}$ & & $31.2 \pm 3.4^{\mathrm{A}}$ & $1.06 \pm 0.06^{\mathrm{AB}}$ \\
15 & $30.5 \pm 3.1^{\mathrm{B}}$ & $1.15 \pm 0.06^{\mathrm{B}}$ & & $30.8 \pm 2.6^{\mathrm{A}}$ & $1.08 \pm 0.05^{\mathrm{B}}$ \\
20 & $28.6 \pm 2.7^{\mathrm{A}}$ & $1.20 \pm 0.08^{\mathrm{C}}$ & & $31.0 \pm 2.8^{\mathrm{A}}$ & $1.15 \pm 0.06^{\mathrm{C}}$ \\
& & & & \\
Isolates & & & & \\
PR1 & $33.4 \pm 2.7^{\mathrm{D}}$ & $1.09 \pm 0.06^{\mathrm{A}}$ & & $33.9 \pm 3.2^{\mathrm{B}}$ & $1.06 \pm 0.08^{\mathrm{B}}$ \\
PR2 & $30.4 \pm 2.3^{\mathrm{BC}}$ & $1.13 \pm 0.07^{\mathrm{B}}$ & & $31.3 \pm 2.6^{\mathrm{A}}$ & $1.04 \pm 0.05^{\mathrm{AB}}$ \\
PR3 & $29.6 \pm 3.0^{\mathrm{B}}$ & $1.13 \pm 0.09^{\mathrm{B}}$ & & $31.2 \pm 3.4^{\mathrm{A}}$ & $1.06 \pm 0.06^{\mathrm{AB}}$ \\
PR4 & $28.2 \pm 2.0^{\mathrm{A}}$ & $1.10 \pm 0.07^{\mathrm{A}}$ & & $30.4 \pm 3.1^{\mathrm{A}}$ & $1.03 \pm 0.06^{\mathrm{A}}$ \\
PR5 & $31.4 \pm 3.1^{\mathrm{C}}$ & $1.07 \pm 0.06^{\mathrm{A}}$ & $31.2 \pm 3.9^{\mathrm{A}}$ & $1.03 \pm 0.07^{\mathrm{A}}$ \\
PR6 & $31.0 \pm 2.4^{\mathrm{C}}$ & $1.07 \pm 0.06^{\mathrm{A}}$ & $30.2 \pm 2.6^{\mathrm{A}}$ & $1.03 \pm 0.06^{\mathrm{A}}$ \\
\hline
\end{tabular}

second sub-clade within $P$. reticulatum ("Clade B" according to Akselman et al., 2015, Fig. 3).

\subsection{Growth of Protoceratium reticulatum}

\subsubsection{Intra-species variability of growth}

All six isolates grown at $10{ }^{\circ} \mathrm{C}$ displayed exponential growth with a cell yield at stationary phase ranging from 5 to $8 \times 10^{3}$ cells $\mathrm{mL}^{-1}$ (Suppl. Fig. S1). Exponential growth rate ranged from $0.06 \pm 0.00 \mathrm{~d}^{-1}$ (PR5) to $0.19 \pm 0.00 \mathrm{~d}^{-1}$ (PR3) (Fig. 4A). Analysis of variance and post-hoc Tukey's HSD tests revealed significant differences $(P<0.05)$ between the isolates, with the exception of the pair of PR1 and PR6 (Fig. 4A).

\subsubsection{Growth of isolate PR3 at different temperatures}

Cells of Protoceratium reticulatum PR3 performed exponential growth at all the experimental temperatures, except for the cultures transferred from $20^{\circ} \mathrm{C}$ to $25^{\circ} \mathrm{C}$ where stocks rapidly decreased in density and completely disappeared two weeks after inoculation. Cultures maintained at $1{ }^{\circ} \mathrm{C}$ reached stationary phase after 56 days of incubation, whereas cultures incubated at both $15^{\circ} \mathrm{C}$ and $20^{\circ} \mathrm{C}$ achieved stationary phase after eleven days (Suppl. Fig. S2). The maximum cell density at stationary phase varied between 6 and $9 \times 10^{3}$ cells $\mathrm{mL}^{-1}$. Most obviously visible for cultures grown at $10^{\circ} \mathrm{C}$ there was a gradual deviation from the highest exponential growth before reaching the stationary phase (Suppl. Fig. S2).

Exponential growth rate increased with temperature (Fig. 4B) reaching the maximum at $15^{\circ} \mathrm{C}\left(0.27 \pm 0.01 \mathrm{~d}^{-1}\right)$ closely followed by the growth performance at $20^{\circ} \mathrm{C}\left(0.25 \pm 0.01 \mathrm{~d}^{-1}\right)$. The lowest growth rate was measured at $1{ }^{\circ} \mathrm{C}\left(0.05 \pm 0.00 \mathrm{~d}^{-1}\right)$ (Fig. 4B). Growth rate was significantly different $(P>0.05)$ between all treatments.

\subsection{Yessotoxins}

\subsubsection{YTX profiles of the Protoceratium reticulatum isolates}

Cells of Protoceratium reticulatum of all isolates produced YTX in both exponential and stationary phase under all temperatures tested. Mass spectrometric analysis showed that the YTX profiles of all isolates were very similar and that the major compound was YTX. Other compounds were detected as minor components in all strains except for PR6, which produced only low concentrations of YTX and minor components might have fallen below the limit of detection. Yessotoxin comprised more than $95 \%$ of total YTX content in most samples. A few minor putative YTX isomers, however, could be identified in SRM experiments. The most abundant of them was a compound with mass transition $m / z 1101>921$ that is equal to norYTX, which reached a maximum of about $5 \%$ of total YTX in strain PR4. The second most abundant of these minor compounds had the mass transition $m / z 1047>967$ which corresponds to 41-keto-YTX or two of its isomers. Other compounds found at trace levels and never exceeding $1 \%$ in any of the samples were $m / z \quad 1157>1077$ (hydroxy-YTX), $m / z 1175>1095$ (dihydroxy-YTX), m/z $1189>$ $1109, \mathrm{~m} / \mathrm{z} 1273>1193, \mathrm{~m} / \mathrm{z} 1157>1077, \mathrm{~m} / \mathrm{z} 1290>1210$, and $m / z 1405>1325$.

\subsubsection{Intra-specific variability YTX}

For all isolates, YTX were detected in cell extract and culture medium. Total YTX per cell was variable among isolates ranging in exponential phase from $15.0 \pm 2.1 \mathrm{pg} \mathrm{YTX} \mathrm{cell}^{-1}$ (PR1) down to the lowest cell quota of $0.3 \pm 0.1 \mathrm{pg}$ YTX cell ${ }^{-1}$ (PR6) (Fig. 5A). Compared to the exponential phase, a roughly two-to-four fold-increase of total YTX cell quota was measured at stationary phase, ranging from $31.0 \pm 6.2$ (PR3) to $0.5 \pm 0.1$ (PR6) pg YTX cell ${ }^{-1}$ (Fig. 5B). For exponential growth the proportion between intra- and extracellular YTX was roughly $50 \%$, whereas in stationary growth phase the 


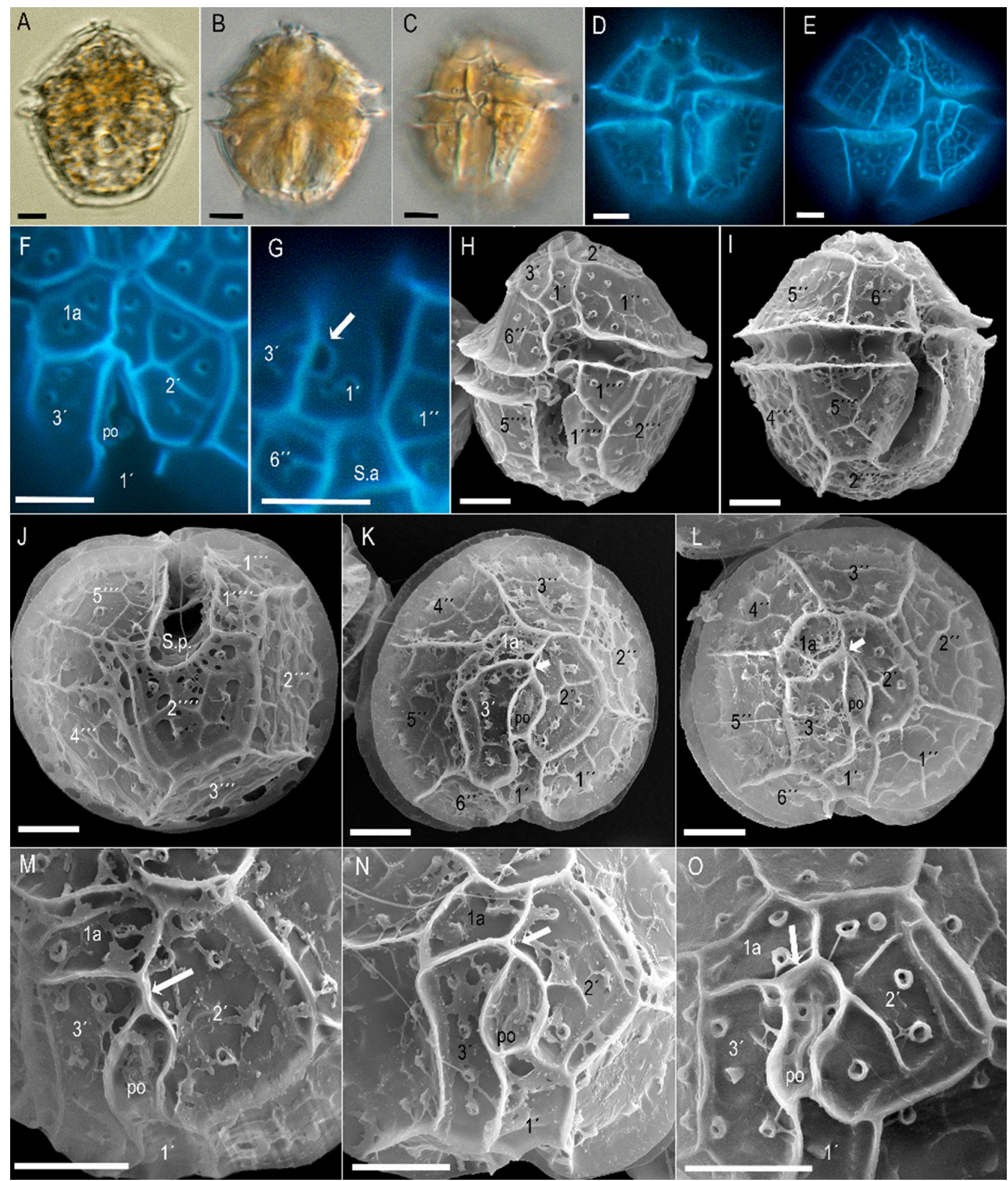

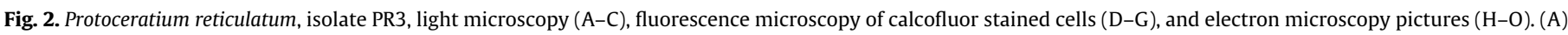

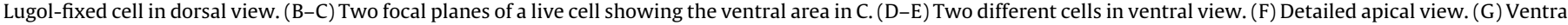

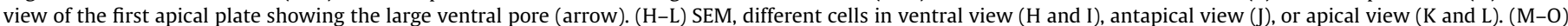
Detailed apical view of the apical pore and the apical plates of different cells. Note the different arrangement of Plate $1 \mathrm{a}($ arrows). Scale bars $=5 \mu \mathrm{m}$.

extracellular proportion was lower (Fig. 5). Analysis of variance and Post-Hoc analysis revealed significant differences of total YTX cell quotas of different isolates for both exponential and stationary phase, with homogenous groups without significant differences $(P>0.05)$ as indicated in Fig. 5.

\subsubsection{YTX of isolate PR3 at different temperatures}

Total YTX of isolate PR3 at different temperatures in exponential phase ranged from $12.5 \pm 0.2$ to $36.4 \pm 7.1 \mathrm{pg}$ cell $^{-1}$ at $15^{\circ} \mathrm{C}$ and $1{ }^{\circ} \mathrm{C}$, respectively (Fig. 6A), with cultures grown at $1{ }^{\circ} \mathrm{C}$ being significantly different from the other temperatures. For stationary 


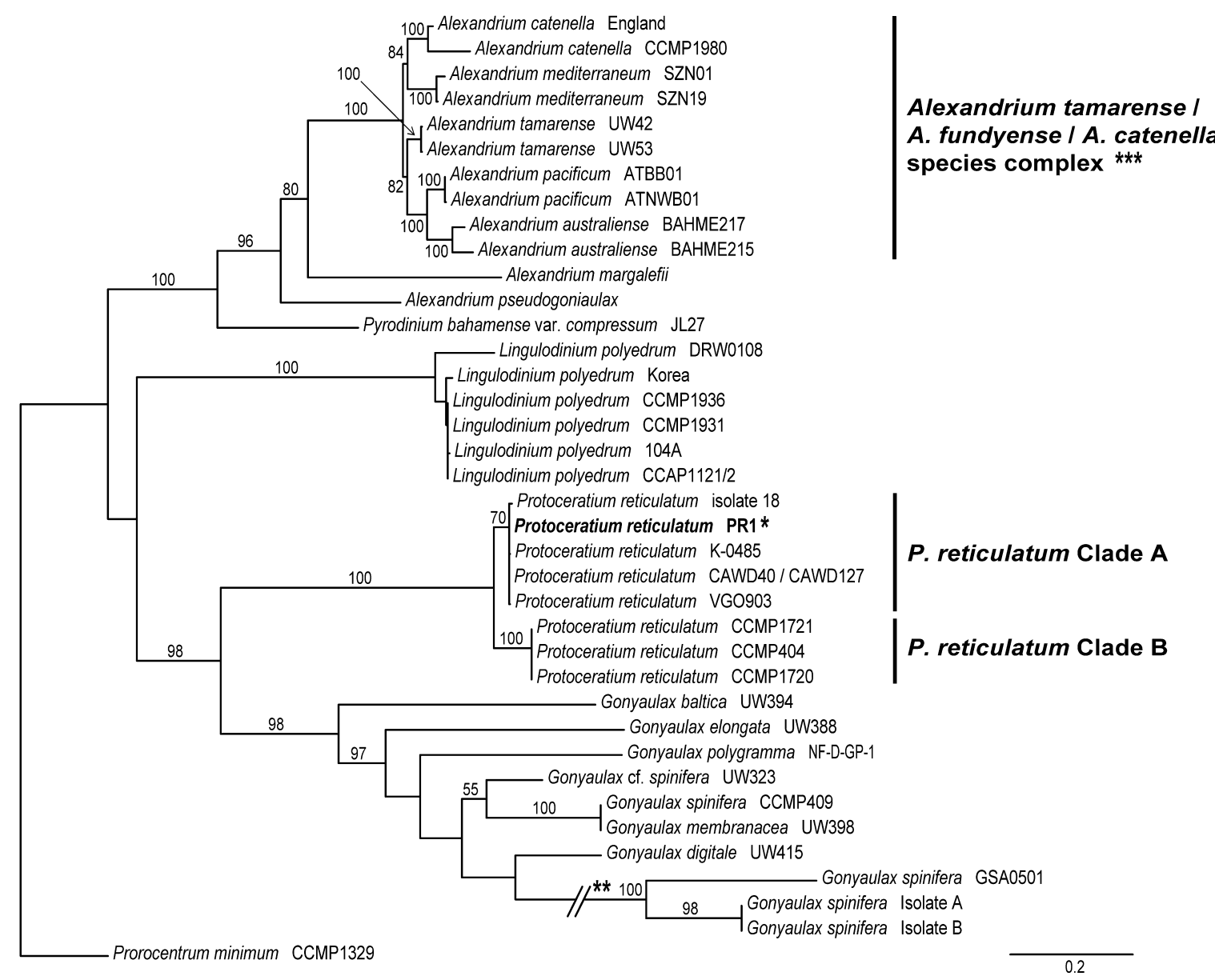

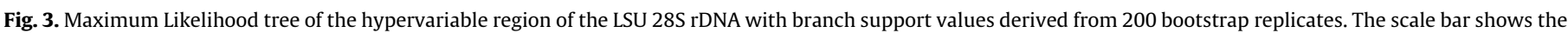

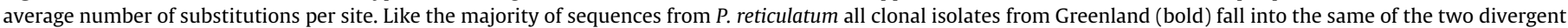

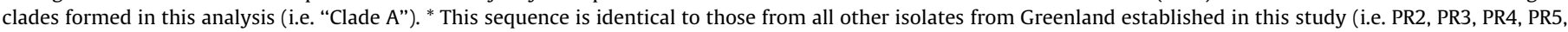

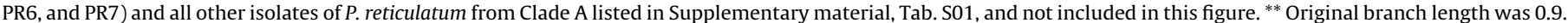

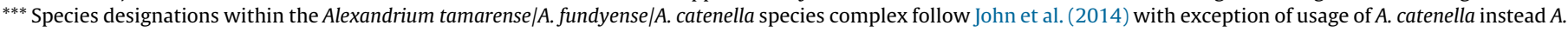
fundyense according to Fraga et al. (2015).

phase cultures an increase of the YTX cell quota was obvious at all temperatures, except at $1{ }^{\circ} \mathrm{C}$, where the lowest total YTX cell quota of $16.8 \pm 2.7 \mathrm{pg}$ cell $^{-1}$ was determined. Extracellular YTX accounted for $28-48 \%$ of total YTX during exponential growth (Fig. 6A). In stationary phase this contribution of extracellular compounds to total YTX was generally lower ranging from 3 to $24 \%$, with the exception of cultures grown at $1{ }^{\circ} \mathrm{C}$ (Fig. 6B).

\subsection{Lytic activity}

All Protoceratium reticulatum isolates were found to produce lytic compounds. An initial experiment was performed to quantify lytic activity of the isolate PR3 for whole culture, cell-free supernatant, and cell extract (Fig. 7). The lowest $\mathrm{EC}_{50}$ ( 838 cells $\mathrm{mL}^{-1}$, i.e. the highest lytic activity) was estimated for the whole culture, followed by the lytic activity of cell-free supernatant, where a decrease of about $50 \%$ of the lytic activity was measured $\left(\mathrm{EC}_{50}=1889\right.$ cells $\left.\mathrm{mL}^{-1}\right)$. No lytic activity was observed in the bioassay performed using algal extract from cell pellets, despite the much higher cellular doses applied (Fig. 7).

\subsubsection{Lytic activity of the isolate PR3 at different temperatures}

The clonal isolate PR3 caused cell lysis of the cryptophyte Rhodomonas salina at all growth temperatures and growth phases (Suppl. Fig. S3, Fig. 8). At exponential phase $\mathrm{EC}_{50}$ ranged from $621 \pm 93$ to $933 \pm 66$ cells $\mathrm{mL}^{-1}$ at $1{ }^{\circ} \mathrm{C}$ and $5^{\circ} \mathrm{C}$, respectively (Fig. 8).
No significant differences $(P<0.05)$ were found between the experimental temperatures, with the exception of the cultures grown at $1{ }^{\circ} \mathrm{C}$, which were significantly different to cultures grown at 5 , 10 and $15^{\circ} \mathrm{C}$. Compared to exponential phase, the $\mathrm{EC}_{50}$ at stationary phase decreased (lytic activity increased) for almost all experimental temperatures except for cultures maintained at $1{ }^{\circ} \mathrm{C}$, for which a slight decrease in the lytic activity was measured. The lowest $\mathrm{EC}_{50}$ was measured at $10^{\circ} \mathrm{C}\left(307 \pm 83\right.$ cells $\left.\mathrm{mL}^{-1}\right)$. Lytic activity at stationary phase was not significantly different for different growth temperatures $(P>0.05)$, with the exception of cultures grown at $1{ }^{\circ} \mathrm{C}$ (Fig. 8).

\subsubsection{Intraspecific comparison of lytic activity}

Other isolates were compared to PR3 based on three-point (exponential phase) or four-point (stationary phase) dilution bioassays (Suppl. Fig. S4). Estimates of $\mathrm{EC}_{50}$ based on visually fitting a sigmoidal curve to the data point are listed in Table 3. High variability in terms of lytic activity was obvious between the six isolates of Protoceratium reticulatum. For the exponential phase sampling, four of the six clonal isolates of $P$. reticulatum showed lytic activity, whereas the isolates PR5 and PR6 did not cause any measurable lysis of Rhodomonas salina at these cell densities. Nevertheless, for these two isolates weak lytic activity was observed at the higher cell densities in stationary phase with $\mathrm{EC}_{50}$ values of about $7.9 \times 10^{3}$ cells $\mathrm{mL}^{-1}$ and $16 \times 10^{3}$ cells $\mathrm{mL}^{-1}$, respectively (Table 3 ). 


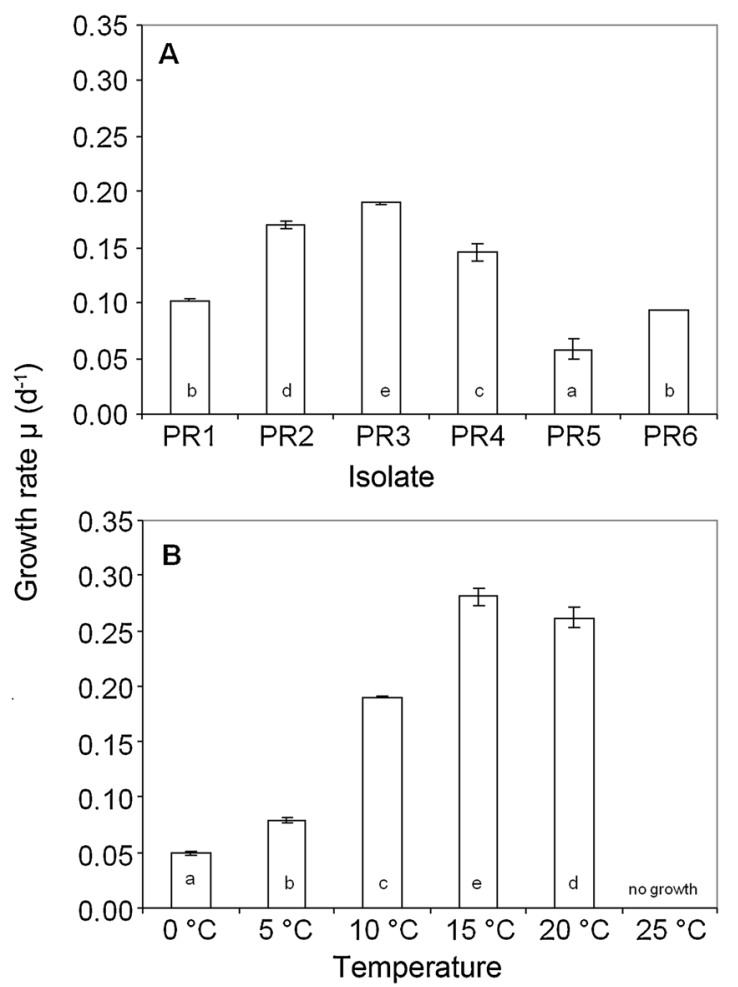

Fig. 4. Growth rate $\mu\left(\mathrm{d}^{-1}\right)$ of Protoceratium reticulatum (A) for all isolates grown at $10{ }^{\circ} \mathrm{C}$, and (B) for isolate PR3 as a function of experimental temperatures. Data points represent mean of three replicates cultures $( \pm S D)$. Different letters indicate significant differences between treatments (ANOVA, Tukey's HSD test, $P<0.05$ ).

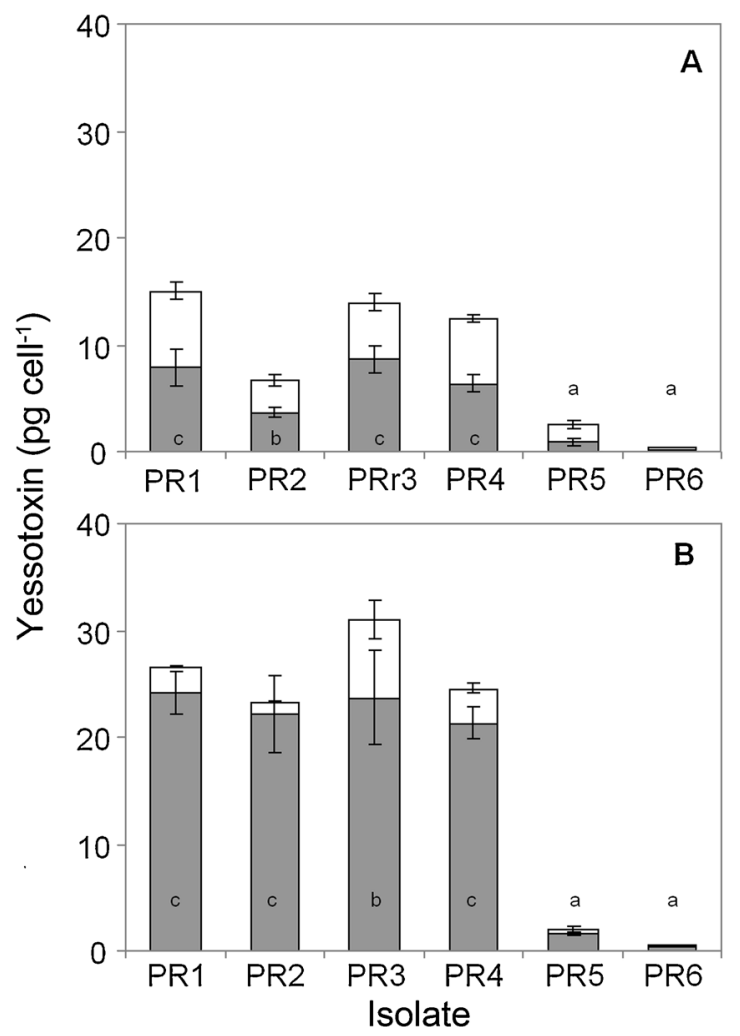

Fig. 5. Protoceratium reticulatum, all isolates grown at $10{ }^{\circ} \mathrm{C}$. Yessotoxin (YTX) content per cell in exponential (A) and stationary (B) growth. Cumulative bars composed of intracellular (grey bars) and extracellular (white bars) YTX. Data points represent mean of three replicates cultures $( \pm S D)$. Different letters indicate significant differences between isolates (ANOVA, Tukey's HSD test, $P<0.05$ ).

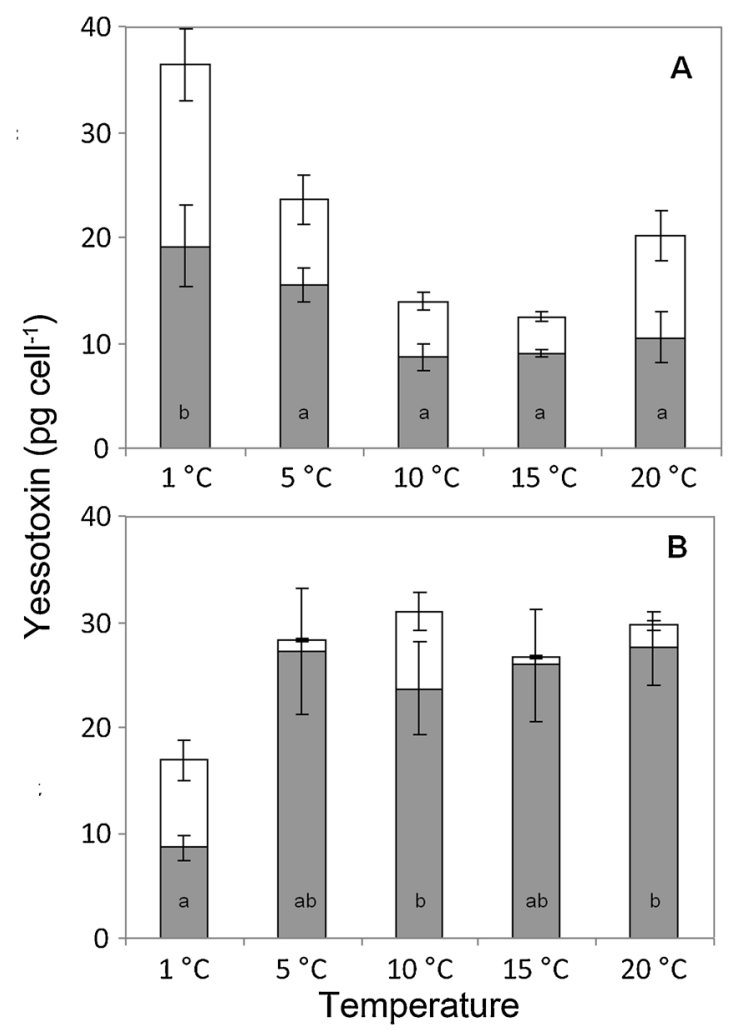

Fig. 6. Protoceratium reticulatum, isolate PR3. Yessotoxin (YTX) content per cell at various growth temperatures in exponential (A) and stationary (B) growth. Cumulative bars composed of intracellular (grey bars) and extracellular (white bars) YTX. Data points represent mean of three replicates cultures $( \pm S D)$. Different letters indicate significant differences between isolates (ANOVA, Tukey's HSD test, $P<0.05)$.

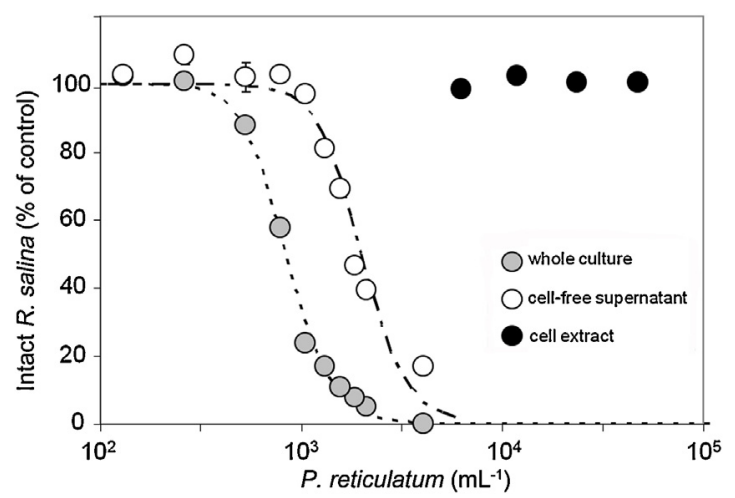

Fig. 7. Dose-response curves describing the lytic activity of three different culture fractions (whole culture, cell-free supernatant and algal cell extract). Data points represent the concentration of Rhodomonas salina after $24 \mathrm{~h}$ incubation (as percent of control) as a function of log-transformed Protoceratium reticulatum concentration. Each data point represents a mean with error bars indicating the range of the two technical replicates. Lines represent a nonlinear, sigmoidal curve fit.

\section{Table 3}

Protoceratium reticulatum lytic activity expressed as $\mathrm{EC}_{50}$ (cells $\mathrm{mL}^{-1}$ ) of all isolates grown at $10^{\circ} \mathrm{C}$ in exponential and stationary growth phase. Detailed Results of PR3 ( \pm 1 SD, see full dose response curves in Suppl. Fig. S3) are listed for comparison. Doseresponse curves of the other isolates can be found in Suppl. Fig. S4. $\mathrm{EC}_{50}$ for PR5 and PR6 at exponential phase could not be calculated as there was insignificant lysis at the highest cell concentration.

\begin{tabular}{lrrllll}
\hline & PR1 & PR2 & PR3 & PR4 & PR5 & PR6 \\
\hline Exponential & 470 & 2800 & $932 \pm 65$ & 640 & Not calculated & Not calculated \\
Stationary & 380 & 640 & $307 \pm 83$ & 320 & 7900 & 16000 \\
\hline
\end{tabular}




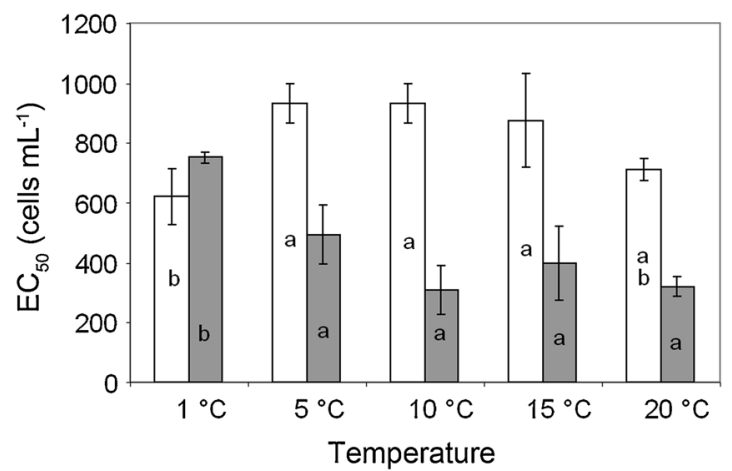

Fig. 8. Protoceratium reticulatum, isolate PR3. Lytic activity expressed as $\mathrm{EC}_{50}$ (cells $\mathrm{mL}^{-1}$ ) at exponential (white bars) and stationary (grey bars) growth at various growth temperatures. Note that high lytic activity correspond to low $\mathrm{EC}_{50}$. Data points represent mean values of three replicate cultures $( \pm \mathrm{SD})$. Different letters indicate significant differences between treatments (ANOVA, Tukey's HSD test, $P<0.05)$.

\section{Discussion}

Several studies have reported the presence of either Protoceratium reticulatum or YTX in mussels in the Arctic Ocean (Okolodkov, 2005; Vershinin et al., 2006; Poulin et al., 2011). The Greenland isolates of $P$. reticulatum, as verified by detailed morphologic and phylogenetic analysis, are the first isolates grown in culture of this species from arctic waters. All tested isolates have been identified as YTX producers. In addition, they have been shown to produce extracellular lytic compounds, which make this work the first report of allelochemical activity in P. reticulatum.

Many studies have proven a high variability of various traits among different strains or isolates of microalgae species even within the same local population (Maranda et al., 1985; Costas, 1990; Orlova et al., 2007; Tillmann et al., 2009; Alpermann et al., 2010). This is important to keep in mind when discussing differences between species for any ecophysiological trait, as interspecific differences can only be evaluated when the range of intraspecific variability for a given species is known. In any interspecies comparison, it is thus important to include, if possible, multiple strains or isolates of the species (or local populations) that are to be compared (Burkholder and Glibert, 2006). The current study thus included an assessment of traits of six isolates in order to evaluate intraspecific variability of Protoceratium reticulatum from arctic waters from off the West coast of Greenland. Whereas morphology (albeit small differences in cell size) and molecular data did not differentiate the isolates, they showed a large variability in all other trait parameters assessed herein, including growth rate, YTX production, and lytic activity. Despite this high variability among strains, this time exemplarily only one isolate was used for a detailed study of temperature response, but other isolates might differ in their physiological behaviour.

\subsection{Morphology and phylogeny}

Morphology as well as the phylogenetic analysis identified all isolates as Protoceratium reticulatum. Cell size was variable within all isolates but corresponded to size ranges reported in the literature (Dodge, 1989; Hansen et al., 1996/97). As exemplified for isolate PR3, there was some variability in the position of the intercalary Plate 1a theoretically causing different plate patterns within the population by having either three or four apical plates (i.e. plates with contact to the pore plate). Cells of $P$. reticulatum indeed have been reported either with four apical (Woloszynska, 1929) or with three apical (as Gonyaulax grindleyi,
Reinecke, 1967) plates. The careful work of Hansen et al. (1996/97), however, revealed that nearly half of the $P$. reticulatum specimen analyzed from Danish field samples showed contact between 1a and the pore plate. Thus, such variability in the position of Plate 1a seems to be a common feature of $P$. reticulatum.

As pointed out by Akselman et al. (2015), isolates of Protoceratium reticulatum belong to one of two clearly divergent clades (Clade A and Clade B) based on phylogenetic analyses of their LSU rDNA sequences and these two clades might be recognized as distinct species when morphological characters are studied in more detail. The seven isolates from waters off the West coast of Greenland (of which only six could be maintained for morphological and physiological analysis in this study) all belong to Clade A described by Akselman et al. (2015). This clade is widespread beyond arctic waters and isolates have been obtained from the western and eastern coasts of the South and North Atlantic, including the Mediterranean, and the western and eastern North Pacific and from the South Pacific. Nothing is known so far on the intra-specific genetic divergence or genetic structure among regional populations of this clade, but the diversity in phenotypic traits as shown in this study suggests that underlying genetic determinants are not homogenously distributed within local populations. Hence, local populations of $P$. reticulatum can be expected to be subject to differential selection pressures on an individual level as well as to neutral genetic differentiation of populations by genetic drift (although drift might be comparatively small in large planktonic populations). As soon as more clonal strains from other regional populations become available the pattern of connectivity among regional populations of this species can be assessed and it will become possible to confirm or disprove the questionable existence of an autochthonous arctic population of $P$. reticulatum (see below).

\subsection{Growth rate}

Growth rate is a significant parameter in population dynamics and phytoplankton ecology as it integrates numerous biochemical processes to yield a single resultant "output", usually defined in terms of changes in cell number or biomass. It is known that natural populations of dinoflagellates show a high intraspecific variability in terms of growth rate (Brand, 1981; Costas, 1990), and the growth rate variability of different isolates of Protoceratium reticulatum from Greenland grown under exactly the same environmental conditions agrees with this conclusion. In any case, growth rate is an important measure to quantify the effect of any environmental factor. Among those, temperature is important as it significantly influences phytoplankton dynamics and geographical distribution (Guerrini et al., 2007). For this reason one of the isolates was selected and tested for a wide range of temperatures to establish a base line of the physiology of this arctic $P$. reticulatum isolate. Maximum growth at $15^{\circ} \mathrm{C}$, close to growth at $20^{\circ} \mathrm{C}$, and low growth rates at $1{ }^{\circ} \mathrm{C}$ and $5{ }^{\circ} \mathrm{C}$ might be taken as an indication of a generally better adaptation of $P$. reticulatum to temperate waters than cold waters. This concurs with the review published by Okolodkov (2005), as P. reticulatum has a rather wide distribution, but the majority of records of this species come from temperate areas. Moreover, blooms of $P$. reticulatum have exclusively been reported from temperate areas, such as a bloom in Flødevigen (Norway) (Aasen et al., 2005), a bloom in northern Japan (Koike et al., 2006), or a bloom in northern Chile (Álvarez et al., 2011), which all occurred at water temperatures of $13-21{ }^{\circ} \mathrm{C}$. In addition to these in situ evidences, few laboratory studies have tested temperature effects on growth of $P$. reticulatum isolates from different locations, such as the Adriatic Sea (Guerrini et al., 2007), the North Sea (Röder et al., 2012) and from NW Spain (Paz et al., 2006). All these studies 
support the general conclusion that $P$. reticulatum is a temperate water species. Nevertheless, isolates from the Mediterranean, with maximum growth at $20^{\circ} \mathrm{C}$, were still growing at growing at $26^{\circ} \mathrm{C}$ (Guerrini et al., 2007). Compared to the Greenland isolate, which died at $25{ }^{\circ} \mathrm{C}$, this indicates that geographically different populations may differ in their temperature adaptation status. Even though the arctic isolate PR3 shows its fastest growth at $15^{\circ} \mathrm{C}$, it is important to note that this isolate still is actively growing at $1{ }^{\circ} \mathrm{C}$, albeit at a low rate corresponding to a doubling time of about 10 days. Unfortunately, for other isolates of Protoceratium there are no growth rate data available at such low temperature, which would allow for a more detailed evaluation of a low-temperature adaptation of arctic isolates and the existence of specific cold water adaptation in arctic $P$. reticulatum populations remains to be shown. In any case, with a doubling time of about 10 to 7 days for the temperature range of $1-5{ }^{\circ} \mathrm{C}$ is seems unlikely that $P$. reticulation will be able to form blooms in arctic areas, given the short duration of the growth season and prevailing low water temperature in the Arctic. In Disco Bay, Greenland, the area where all but one $P$. reticulatum isolates were collected, summer (JuneAugust) surface water $(0-50 \mathrm{~m})$ temperature ranged between $-1.5^{\circ} \mathrm{C}$ and $10.3^{\circ} \mathrm{C}$ for the period between 1924 and 2010 (Hansen et al., 2012) with higher water temperatures of 5 to $10{ }^{\circ} \mathrm{C}$ recorded only during the late phase of the growth season.

\subsection{Yessotoxins}

The arctic isolates of $P$. reticulatum examined in this study revealed toxin profiles which are consistent with those of most other isolates from the Atlantic with more than 95\% YTX of total YTX content being the most abundant congener. For example, Krock et al. (2006) found YTX as the major congener in $P$. reticulatum isolated from the Scottish East coast (North Sea) and from the Benguela Current, SE Atlantic, where in both cases YTX dominated the toxin profile with over 95\%. The same was found for isolates from the Andalusian Atlantic coast (NE Atlantic) and the Catalan coast (Alfacs Bay, Mediterranean) (Paz et al., 2007). The authors however reported that one out of three isolates from the same bay produced $96 \%$ homo-YTX as the major congener. In contrast, $P$. reticulatum isolated from Helgoland Roads (North Sea) and the Galician Rias (NW Spain) again showed profiles dominated by YTX with more than 95\% (Röder et al., 2012; Paz et al., 2013).

The most abundant of the minor YTX was a compound with $m / z$ 1101 consistent with nor-YTX (Miles et al., 2005a). Even though its identity due to the lack of an analytical standard cannot be confirmed, it is obvious that this compound with a smaller molecular mass as YTX most likely is a truncated or not fully developed YTX and might be a precursor or side product of YTX biosynthesis. The same applies to $\mathrm{m} / \mathrm{z} 1047$ which could be 41 -keto YTX or one of its isomers (Miles et al., 2005a) with its almost 100 Da lower molecular weight in comparison to YTX. In contrast the other four minor congeners seem to be substituted forms of YTX: $m / z 1157$ a hydroxylated and $m / z 1175$ a dihydroxylated variant. Furthermore the arctic isolates produced $m / z$ 1290, which has been reported as a hydoxyamide YTX (Miles et al., 2005b). This hydroxyamide YTX, however, is derived from homo-YTX, which has not been detected in the arctic isolates. For this reason, the identity of $m / z 1290$ of the arctic isolates with hydroxyamide described by Miles et al. (2005b) is questionable. The last of the minor compounds with $\mathrm{m} / \mathrm{z} 1405$ is consistent with $32-O-[\beta-\mathrm{L}-$ arabinofuranosyl- $\left(5^{\prime} \rightarrow 1^{\prime \prime}\right)-\beta$-L-arabinofuranoside] described in Miles et al. (2006). Since this compound is a glucoside derived from YTX, its production by the arctic Protoceratium reticulatum is likely. Since analytical standards are lacking for all variants of YTX an unambiguous identification of these congers within this study was not possible and further work is necessary to identify and confirm those compounds as YTX congers.

A number of phycotoxins, including saxitoxins and derivatives as well as spirolides, are generally assumed to be primarily intracellular compounds with little excretion or leakage from cells during exponential growth (Cembella, 2003). For YTX of Protoceratium reticulatum, a significant amount was found in the culture medium, although the percentage of intracellular YTX of all strains at all experimental conditions was higher than extracellular YTX. This was observed as well for other strains of $P$. reticulatum (Paz et al., 2004, 2013; Guerrini et al., 2007; Röder et al., 2012), although it has to be kept in mind that these authors did not report on extraction efficiency of their SPE method to quantify extracellular YTX and thus the true extracellular concentrations in their experiment might have been higher. A general feature observed for all Greenland isolates and in the studies cited above was an increase in intracellular YTX cell quota at stationary phase. This increase can be explained when cells in stationary phase stop dividing but retain metabolic activity leading to an accumulation of secondary metabolites in the cell. In contrast, extracellular YTX of the arctic isolates on a per-cell basis was generally higher in exponential than in stationary growth phase. This was observed for all six strains as well for all temperature treatments of strain PR3 and thus seems to be general feature among the arctic $P$. reticulatum strains. This might indicate an increased excretion of these compounds by actively growing cells, but it also might reflect an increased degradation of extracellular metabolites in old cultures as bacterial densities usually peak when algae become dense. In contrast, other studies (Paz et al., 2004; Guerrini et al., 2007) have found increasing per-cell extracellular concentrations of YTX in stationary phase, which is commonly discussed as a stress related release due to cell leakage or death. Clearly, more detailed studies are needed to fully evaluate the significance, variability, and potential role of extracellular YTX.

Total (intra- and extracellular) YTX cell quotas of the six isolates measured in this study ranged from 0.3 to $31.0 \mathrm{pg} \mathrm{YTX} \mathrm{cell}^{-1}$. Together with YTX cell quotas of other isolates (Rhodes et al., 2006; Guerrini et al., 2007; Paz et al., 2007, 2013; Röder et al., 2012), which cover a similarly wide range, this indicates that both, strains from different areas, and isolates from a single population, can be quite different in terms of YTX production. Some strains in the literature have been identified as non-toxigenic, i.e. one isolate from New Zealand (Rhodes et al., 2006), and three isolates from the US (Paz et al., 2007). Yet a lack of YTX largely depends on the sensitivity of the method and the limit of detection. For example, YTX content of isolate PR6 was rather low and might have gone unnoticed when using other detection methods or lower biomass, and it thus still has to be verified if there are $P$. reticulatum, which completely lack the ability to synthesize YTX.

Higher temperatures did not enhance cell quota of Protoceratium reticulatum $\mathrm{PR} 3$. This is in line with findings for a North Sea P. reticulatum (Röder et al., 2012), but different to other studies (Paz et al., 2006; Guerrini et al., 2007), where a higher YTX cellular concentration was measured at higher temperatures. Towards the lower end of temperatures, in exponential growth there was a clear increase in total YTX yielding an almost 3-fold increase at $1{ }^{\circ} \mathrm{C}$ compared to $15^{\circ} \mathrm{C}$. Growth at the low temperature was rather slow and thus a small difference between growth rate and a production rate of a secondary metabolite might lead to intracellular accumulation comparable to what is observed when growth stops at stationary phase.

\subsection{Lytic activity}

This is the first report on lytic activity of Protoceratium reticulatum. Allelochemical, or lytic activity in marine phytoplankton 
is an emerging field, and numerous reports have published negative effects in protist interactions such as inhibition of growth or photosynthesis or even death of competitors or grazers (Cembella, 2003; Legrand et al., 2003; Ianora et al., 2011). Allelochemical effects are well documented for a number of dinoflagellate HAB species and were found to be unrelated to the presence of the known phycotoxins. This has been shown for Karenia brevis (Kubanek et al., 2005), where the neurotoxin brevetoxin was shown not to be responsible for negative effects on other plankton algae, for Alexandrium tamarense, whose lytic activity was unrelated to the PSP toxins (Tillmann and John, 2002), and for Alexandrium ostenfeldii, whose cyclic imine toxins likewise were shown not to be responsible for lysis of other cells (Tillmann et al., 2007). For P. reticulatum, the present data also provide some evidence that yessotoxins are not directly linked to lytic activity. This evidence is based on the lack of lytic activity of cell extract compared to high lytic activity of cell free supernatant. Even though a significant proportion of YTX were found extracellular in the culture medium, the majority of YTX was in the cells, making lytic activity of YTX unlikely.

Temperature seems to have no major effect on lytic activity except for the cultures maintained at $1{ }^{\circ} \mathrm{C}$, where the $\mathrm{EC}_{50}$ measured at exponential phase was significantly lower, i.e. the cells were more lytic. This is probably due to the very slow growth rate at that temperature. Generally, a mismatch between growth rate and the rate of production of secondary metabolites may lead to an accumulation of compounds. Such an accumulation of lytic compounds in the culture medium can generally be seen in stationary phase, where for almost all temperatures and for all strains a two to three fold decrease of $\mathrm{EC}_{50}$ (corresponding to an increase in lytic activity) was recorded. As discussed before for YTX, such an increase in lytic activity at stationary phase may be explained by an accumulation of compounds, when cell division but not the production of secondary metabolites comes to rest.

\subsection{Summary and conclusion}

In this work the presence of the dinoflagellate Protoceratium reticulatum on the West coast of Greenland was confirmed and the first clonal cultures of this species from arctic waters were established. All isolates formed part of the same widespread phylogenetic sub-clade within $P$. reticulatum and produced YTX. In addition, this is the first report of allelochemical activity for this species. The growth response of one isolate over a wide range of temperatures with high growth rates at $15^{\circ}$ and $20^{\circ} \mathrm{C}$ generally suggest an adaptation of the arctic population to temperate waters and therefore eventually a recent origin from other regional populations. Nevertheless, cultures grew significantly at low temperatures $\left(1^{\circ} \mathrm{C}\right.$ to $5{ }^{\circ} \mathrm{C}$ ), but the corresponding doubling times of about 10 to 7 days are rather long and, together with the short summer growth period in the Arctic, seem to not support the idea of $P$. reticulatum as an arctic bloom forming species. Temperature has not shown a major effect on YTX cell quota and $\mathrm{EC}_{50}$ of $P$. reticulatum; on the other hand both parameters are affected by the growth phase showing an increase about two to four times from exponential to stationary phase among the all six isolates analyzed. A high variability was measured between the isolates for the three physiological parameters tested, and thus the importance of using several different isolates in physiology studies is highlighted.

\section{Acknowledgements}

We greatly acknowledge the help of Wolfgang Drebing (AWI) for analyses of yessotoxins. Captain Bergmann and the crew of the FS Maria S. Merian provided essential assistance and support for the collection of field material. The oceanographic cruise was conducted as a contribution to the SCOR/IOC GEOHAB Core Research Project on HABs in Fjords and Coastal Embayments. Financial support was provided by the PACES research program of the Alfred Wegener Institute as part of the Helmholtz Foundation initiative in Earth and Environment.[SS]

\section{Appendix A. Supplementary data}

Supplementary data associated with this article can be found, in the online version, at doi:10.1016/j.hal.2016.02.004.

\section{References}

Aasen, J., Samdal, I.A., Miles, C.O., Dahl, E., Briggs, L.R., Aune, T., 2005. Yessotoxins in Norwegian blue mussels (Mytilus edulis): uptake from Protoceratium reticulatum, metabolism and depuration. Toxicon 45, 265-272.

Akselman, R., Krock, B., Alpermann, T.J., Tillmann, U., Borel, M., Almandoz, G.O., Ferrario, M.E., 2015. Protoceratium reticulatum (Dinophyceae) in the austral Southwestern Atlantic and the first report on YTX-production in shelf waters of Argentina. Harmful Algae 45, 40-52.

Alpermann, T.J., Tillmann, U., Beszteri, B., Cembella, A.D., John, U., 2010. Phenotypic variation and genotypic diversity in a planktonic population of the toxigenic marine dinoflagellate Alexandrium tamarense (Dinophyceae). J. Phycol. 46, 18-32.

Álvarez, G., Uribe, E., Díaz, R., Braun, M., Marino, C., Blanco, J., 2011. Blooms of the Yessotoxin producing dinoflagellate Protoceratium reticulatum (Dinophyceae) in Northern Chile. J. Sea Res. 65, 427-434.

Anderson, D., Cembella, A., Hallegraeff, G., 2012. Progress in understanding harmful algal blooms: paradigm shifts and new technologies for research, monitoring, and management. Ann. Rev. Mar. Sci. 4, 143-176.

Aune, T., Sorby, R., Yasumoto, T., Ramstad, H., Landsverk, T., 2002. Comparison of oral and intraperitoneal toxicity of yessotoxin towards mice. Toxicon 40, 77-82.

Brand, L.E., 1981. Genetic variability in reproduction rates in marine phytoplankton populations. Evolution 35, 1117-1127.

Burkholder, J.M., Glibert, P.M., 2006. Intraspecific variability: an important consideration in forming generalisations about toxigenic algal species. Afr. J. Mar. Sci. 28, 177-180.

Cembella, A.D., 2003. Chemical ecology of eukaryotic microalgae in marine ecosystems. Phycologia 42, 420-447.

Costas, E., 1990. Genetic variability in growth rates of marine dinoflagellates. Genetica 82, 99-102.

Dodge, J.D., 1989. Some revisions of the family Gonyaulacaceae (Dinophyceae) based on a scanning electron microscopy study. Bot. Mar. 32, 275-298.

Eschbach, E., Scharsack, J., John, U., Medlin, L.K., 2001. Improved erythrocyte lysis assay in microtitre plates for sensitive detection and efficient measurement of haemolytic compounds from ichthyotoxic algae. J. Appl. Toxicol. 21, 513-519.

Fraga, S., Sampedro, N., Larsen, J., Moestrup, Ø., Calado, A.J., 2015. Arguments against the proposal 2302 by John \& al. to reject the name Gonyaulax catenella (Alexandrium catenella). Taxon 64, 634-635.

Franchini, A., Marchesini, E., Poletti, R., Ottaviani, E., 2004. Acute toxic effect of the algal yessotoxin on Purkinje cells from the cerebellum of Swiss CD1 mice. Toxicon 43, 347-352.

Fu, F.X., Tatters, A.O., Hutchins, D.A., 2012. Global change and the future of harmful algal blooms in the ocean. Mar. Ecol. Prog. Ser. 470, 207-233.

Guerrini, F., Ciminiello, P., Dell'Aversano, C., Tartaglinone, L., Fatturoso, E., Boni, L., Pistocchi, R., 2007. Influence of temperature, salinity and nutrient limitation on yessotoxin production and release by the dinoflagellate Protoceratium reticulatum in batch-cultures. Hamful Algae 6, 707-717.

Guindon, S., Gascuel, O., 2003. A simple, fast, and accurate algorithm to estimate large phylogenies by maximum likelihood. Syst. Biol. 52, 696-704.

Hallegraeff, G.M., 1993. A review of harmful algal blooms and their apparent global increase. Phycologia 32, 79-99.

Hallegraeff, G.M., 2010. Ocean climate change, phytoplankton community responses, and harmful algal blooms: a formidable predictive challenge. J. Phycol. 46, 220-235.

Hansen, G., Moestrup, Ø., Roberts, K.R., 1996/97. Light and electron microscopical observations on Protoceratium reticulatum (Dinophyceae). Arch. Protistenkd. 147, 381-391.

Hansen, M.O., Nielsen, T.G.,Stedmon, C.A., Munk, P., 2012. Oceanographic regime shift during 1997 in Disko Bay, Western Greenland. Limnol. Oceanogr. 57, 634-644.

Howard, M.D.A., Smith, G.J., Kudela, R.M., 2009. Phylogenetic relationships of yessotoxin-producing dinoflagellates, based on the large subunit and internal transcribed spacer ribosomal DNA domains. Appl. Environ. Microbiol. 75, 54-63.

Ianora, A., Bentley, M.G., Caldwell, G.S., Casotti, R., Cembella, A.D., Engström-Öst, J., Halsband, C., Sonnenschein, E., Legrand, C., Llewellyn, C.A., Paldaviciene, A., Pohnert, G., Pilkaityte, R., Razinkovas, A., Romano, G., Tillmann, U., Vaiciute, D., 2011. The relevance of marine chemical ecology to plankton and ecosystem function: an emerging field. Mar. Drugs 9, 1625-1648.

John, U., Litaker, R.W., Montresor, M., Murray, S., Brosnahan, M.L., Anderson, D.M., 2014. Formal revision of the Alexandrium tamarense species complex (Dinophyceae) taxonmomy: the introduction of five species with emphasis on molecular-based (rDNA) classification. Protist 165, 779-804. 
Katoh, K., Standley, D.M., 2013. MAFFT Multiple Sequence Alignment Software Version 7: improvements in performance and usability. Mol. Biol. Evol. 30, $772-780$.

Katoh, M., Kuma, M., 2002. MAFFT: a novel method for rapid multiple sequence alignment based on fast Fourier transform. Nucl. Acids Res. 30, 3059-3066.

Keller, M.D., Selvin, R.C., Claus, W., Guillard, R.R.L., 1987. Media for the culture of oceanic ultraphytoplankton. J. Phycol. 23, 633-638.

Koike, K., Horie, Y., Suzuki, T., Kobiyama, A., Kurihara, K., Takagi, K., Kaga, S.N., Oshima, Y., 2006. Protoceratium reticulatum in northern Japan: environmental factors associated with seasonal occurrence and related contamination of yessotoxin in scallops. J. Plankton Res. 28, 103-112.

Krock, B., Alpermann, T.J., Tillmann, U., Pitcher, G.C., Cembella, A.D., 2006. Yessotoxin profiles of the marine dinoflagellates Protoceratium reticulatum and Gonyaulax spinifera. In: Moestrup, Ø. (Ed.), 12th International Conference on Harmful Algae, Copenhagen, Denmark, ISSHA \& IOC of UNNESCO, Copenhagen, pp. 303-305.

Kubanek, J., Hicks, M.K., Naar, J., Villareal, T.A., 2005. Does the red tide dinoflagellate Karenia brevis use allelopathy to outcompete other phytoplankton? Limnol. Oceanogr. 50, 883-895.

Legrand, C., Rengefors, K., Fistarol, G.O., Granéli, E., 2003. Allelopathy in phytoplankton-biochemical, ecological and evolutionary aspects. Phycologia 42, 406-419.

Makino, W., Ito, K., Oshima, Y., Urabe, J., 2008. Effects of Protoceratium reticulatum yessotoxin on feeding rates of Acartia hudsonica: a bioassay using artifical particles coated with purified toxin. Harmful Algae 7, 639-645.

Maranda, L., Anderson, D.M., Shimizu, Y., 1985. Comparison of toxicity between populations of Gonyaulax tamarensis of Eastern North American waters. Estuar. Coast. Shelf Sci. 24, 401-410.

Miles, C.O., Wilkins, A.L., Samdal, I.A., Sandvik, M., Petersen, D., Quilliam, M.A., Naustvoll, L.J., Rundberget, T., Torgersen, T., Hovgaard, P., Jensen, D.J., 2004. A novel pectenotoxin, PTX-12, in Dinophysis spp. and shellfish from Norway. Chem. Res. Toxicol. 17, 1423-1433.

Miles, C.O., Samdal, I.A., Aasen, J.A.G., Jensen, D.J., Quilliam, M.A., Petersen, D., Briggs, L.M., Wilkins, A.L., Rise, F., Cooney, J.M., Lincoln MacKenzie, A., 2005a. Evidence for numerous analogs of yessotoxin in Protoceratium reticulatum. Harmful Algae 4, 1075-1091.

Miles, C.O., Wilkins, A.L., Hawkes, A.D., Selwood, A.I., Jensen, D.J., Munday, R., Cooney, J.M., Beuzenberg, V., 2005b. Polyhydroxylated amide analogs of yessotoxin from Protoceratium reticulatum. Toxicon 45, 61-71.

Miles, C.O., Wilkins, A.L., Selwood, A.I., Hawkes, A.D., Jensen, D.J., Cooney, J.M. Beuzenberg, V., MacKenzie, A.L., 2006. Isolation of Yessotoxin 32-O-[ $\beta-1$-arabinofuranosyl-(5' $\left.\rightarrow 1^{\prime \prime}\right)-\beta$-l-arabinofuranoside] from Protoceratium reticulatum. Toxicon 47, 510-516.

Murata, M., Kumakai, M., Soo Lee, J., Yasumoto, T., 1987. Isolation and structure of yessotoxin, a novel polyether compound implicated in diarrhetic shellfish poisoning. Tetrahedron Lett. 28, 5869-5872.

Okolodkov, Y.B., 2005. The global distributional patterns of toxic, bloom dinoflagellates recorded from the Eurasian Arctic. Harmful Algae 4, 351-369.

Orlova, T., Selina, M.S., Lilly, E.L., Kulis, D.M., Anderson, D.M., 2007. Morphogenetic and toxin composition variability of Alexandrium tamarense (Dinophyceae) from the east coast of Russia. Phycologia 46, 534-548.

Paz, B., Riobó, P., Fernández, M.L., Fraga, S., Franco, J.M., 2004. Production and release of yessotoxins by the dinoflagellates Protoceratium reticulatum and Lingulodinium polyedrum in culture. Toxicon 44, 251-258.

Paz, B., Vázquez, J.A., Riobó, P., Franco, J.M., 2006. Study of the effect of temperature, irradiance and salinity on growth and yessotoxin production by the dinoflagellate Protoceratium reticulatum in culture by using a kinetic and factorial approach. Mar. Environ. Res. 62, 286-300.

Paz, B., Riobó, P., Ramilo, I., Franco, J.M., 2007. Yessotoxins profile in strains of Protoceratium reticulatum from Spain and USA. Toxicon 50, 1-17.
Paz, B., Daranas, A.H., Norte, M., Riobó, P., Franco, J.M., Fernández, J.J., 2008 Yessotoxins, a group of marine polyether toxins: an overview. Mar. Drugs 6, 73-102.

Paz, B., Blanco, J., Franco, J.M., 2013. Yessotoxin production during the culture of Protoceratium reticulatum strains isolated from Galician Rias Baixas (NW Spain). Harmful Algae 21-22, 13-19.

Posada, D., 2008. ModelTest: Phylogenetic model averaging. Mol. Biol. Evol. 25, $1253-1256$.

Poulin, M., Daugbjerg, N., Gradinger, R., Ilyash, L., Ratkova, T., von Quillfeldt, C., 2011. The pan-Arctic biodiversity of marine pelagic and sea-ice unicellular eukaryotes: a first-attempt assessment. Mar. Biodivers. 41, 13-28.

Ramstad, H., Hovgaard, P., Vasumoto, T., Larsen, S., Aune, T., 2001. Monthly variation in diarrhetic toxins and yessotoxins in shellfish from the coast to inner part of Sognefjord, Norway. Toxicon 39, 1035-1043.

Reinecke, P., 1967. Gonyaulax grindleyi sp. nov.: a dinoflagelate causing a red tide at Elands Bay, Cape Province, in december 1966. J. S. Afr. Bot. 33, 157-160.

Rhodes, L., McNabb, P., De Salas, M., Briggs, L., Beuzenberg, V., Gladstone, M., 2006 Yessotoxin production by Gonyaulax spinifera. Harmful Algae 5, 148-155.

Röder, K., Hantzsche, F.M., Gebühr, C., Miene, C., Helbig, T., Krock, B., Hoppenrath, M., Luckas, B., Gerdts, G., 2012. Effects of salinity, temperature and nutrients on growth, cellular characteristics and yessotoxin production of Protoceratium reticulatum. Harmful Algae 15, 59-70.

Satake, M., MacKenzie, L., Yasumoto, T., 1997. Identification of Protoceratium reticulatum as the biogenetic origin of yessotoxin. Nat. Toxins 5, 164-167.

Scholin, C.A., Herzog, M., Sogin, M., Anderson, D.M., 1994. Identification of groupand strain-specific genetic markers for globally distributed Alexandrium (Dinophyceae). II. Sequence analysis of a fragment of the LSU rRNA gene. J. Phycol. 30 999-1011.

Terao, K., Ito, E., Oarada, M., Murata, M., Yasumoto, T., 1990. Histopatological studies on experimental marine toxin poisoning-5. The effects in mice of yessotoxin isolated from Patinopecten yessoensis and of a desulfated derivate. Toxicon 28, 1095-1104.

Tillmann, U., John, U., 2002. Toxic effects of Alexandrium spp. on heterotrophic dinoflagellates: an allelochemical defence mechanism independent of PSP toxins. Mar. Ecol. Prog. Ser. 230, 47-58.

Tillmann, U., John, U., Cembella, A.D., 2007. On the allelochemical potency of the marine dinoflagellate Alexandrium ostenfeldii against heterotrophic and autotrophic protists. J. Plankton Res. 29, 527-543.

Tillmann, U., Alpermann, T., da Purificação, R.C., Krock, B., Cembella, A., 2009. Intrapopulation clonal variability in allelochemical potency of the toxigenic dinoflagellate Alexandrium tamarense. Harmful Algae 8, 759-769.

Tillmann, U., Elbrächter, M., John, U., Krock, B., Cembella, A., 2010. Azadinium obesum (Dinophyceae), a new nontoxic species in the genus that can produce azaspiracid toxins. Phycologia 49, 169-182.

Tillmann, U., Elbrächter, M., John, U., Krock, B., 2011. A new non-toxic species in the dinoflagellate genus Azadinium: A. poporum sp. nov. Eur. J. Phycol. 46, 74-87.

Tillmann, U., Gottschling, M., Nézan, E., Krock, B., Bilien, G., 2014. Morphological and molecular characterization of three new Azadinium species (Amphidomataceae, Dinophyceae) from the Irminger Sea. Protist 165, 417-444.

Toebe, K., Alpermann, T., Tillmann, U., Krock, B., Cembella, A., John, U., 2013. Molecular discrimination of toxigenic and non-toxic Alexandrium species in natural phytoplankton assamblages from the Scottish coast of the North Sea. Eur. J. Phycol. 48, 12-26.

Vershinin, A., Moruchkov, A., Morton, S.L., Leighfield, T.A., Quilliam, M.A., Ramsdell, J.S., 2006. Phytoplankton composition of the Kandalaksha Gulf, Russion White Sea: Dinophysis and lipophilic toxins in the blue mussel (Mytilus edulis). Harmful Algae 5, 558-564.

Wassmann, P., Duarte, C.M., Agustí, S., Sejr, M.K., 2011. Footprints of climate change in the Arctic marine ecosystem. Global Change Biol. 17, 1235-1249.

Woloszynska, J., 1929. Dinoflagellatae der Polnischen Ostsee sowie der an Piasnica gelegenen Sümpfe. Archivum Hydrobiologji I Rybactwa 3, 153-278. 